\title{
Benzylpenicillin-induced Filament Formation of Clostridium perfringens
}

\author{
By RUSSELL WILLIAMSON† AND J. BARRIE WARD* \\ Division of Microbiology, National Institute for Medical Research, Mill Hill, \\ London NW7 1AA, U.K.
}

(Received 19 March 1982; revised 28 April 1982)

\begin{abstract}
Growth of Clostridium perfringens with low concentrations of benzylpenicillin inhibited septum formation and division of the organisms. This resulted in continued growth of the organisms as aseptate filaments. The effect was reversed on removal of the antibiotic. The composition of walls isolated from organisms grown with the antibiotic was similar to that of walls from untreated bacteria. In addition, both contained non- $N$-acetylated glucosamine residues in their peptidoglycan. No differences were detected in the degree of cross-linkage of peptidoglycan. Clostridium perfringens contains six membrane-associated penicillin-binding proteins (PBPs) which have different affinities for $\left[{ }^{3} \mathrm{H}\right]$ benzylpenicillin. Concentrations of the antibiotic which were sufficient to cause filamentation of apparently all organisms in a culture caused almost complete saturation of PBPs 3, 4, 5 and 6. At these concentrations there was no measurable interaction with PBPs 1 and 2. Thus interaction of the antibiotic with the lower molecular weight PBPs is correlated with the inhibition of septum formation in $C$. perfringens.
\end{abstract}

\section{INTRODUCTION}

$\beta$-Lactam antibiotics prevent the growth of bacteria by inhibiting peptidoglycan biosynthesis. However, treatment with concentrations of these antibiotics less than the minimum inhibitory concentration (MIC) often allows continued growth of the bacteria, but with the production of aberrant morphological forms. For example, Escherichia coli grows as filaments in the presence of low concentrations of either cephalexin or piperacillin, whereas higher concentrations cause death of the organism (Spratt, 1975; Iida et al., 1978). Similar effects have been observed in other Gram-negative bacteria (Curtis et al., 1979; Noguchi et al., 1979). In each case the $\beta$ lactam antibiotic causing aberrant growth has a relatively specific affinity for one of the penicillin-binding proteins (PBPs) present in the membrane. In this way PBPs 2 and 3 of $E$. coli appear to be involved in the control of cell extension and septum formation respectively. Binding of suitable antibiotics to these PBPs, or loss of the PBPs in certain morphological mutants, results in growth of the organisms as round forms or filaments (Spratt, 1975, 1977, 1978; Spratt \& Pardee, 1975).

In contrast, $\beta$-lactam antibiotics do not usually have such marked morphological effects on Gram-positive bacteria. However, Gardner (1940) and Crofts \& Evans (1950) reported that low concentrations of benzylpenicillin inhibit septum formation in Clostridium perfringens (formerly C. welchii). We have examined the effect of benzylpenicillin treatment on the growth and wall chemistry of $C$. perfringens and have attempted to determine whether one or more of the PBPs present could be associated with septum formation.

$†$ Present address: The Rockefeller University, 1230 York Avenue, New York, NY 10021, U.S.A.

† Present address: Microbial Biochemistry Department, Glaxo Group Research Ltd, Greenford Road, Greenford, Middlesex UB6 0HE, U.K.

Abbreviations: MIC, minimum inhibitory growth concentration; PBP, Penicillin-binding protein. 


\section{METHODS}

Organisms. Clostridium perfringens NCTC 8237 was obtained from the National Collection of Type Cultures, London, and C. perfringens 667, a phospholipase-deficient strain, from Dr Madeline Seebald, Institut Pasteur, Paris.

Media. The organisms were maintained in Difco cooked meat medium. Cultures were grown in medium (CYE) containing Difco Casamino acids $\left(1 \%\right.$, w/v), Difco yeast extract $(1 \%, \mathrm{w} / \mathrm{v}), \mathrm{KH}_{2} \mathrm{PO}_{4}(0 \cdot 27 \%$, w/v) and supplemented $\left(1 \mathrm{mll}^{-1}\right)$ with the salts solution described by Pollock (1965). The medium was steamed for $15 \mathrm{~min}$ to remove oxygen before use, then cooled and glucose $(0.4 \%, \mathrm{w} / \mathrm{v})$ added. Cultures were grown without aeration at $37^{\circ} \mathrm{C}$. Colonies were grown on plates of Difco AC medium and Becton-Dickinson Gaspacks were used to provide anaerobic conditions.

Antibiotic susceptibility tests. The MICs of several antibiotics were determined by twofold serial dilution in CYE medium. Exponential phase organisms (strain NCTC 8237, approximately $5 \times 10^{4} \mathrm{c.f} . \mathrm{u} . \mathrm{ml}^{-1}$ ) were inoculated into the medium $(2 \mathrm{ml})$ containing dilutions of the antibiotics. The tubes were incubated for $16 \mathrm{~h}$, and the lowest concentration to inhibit growth of the bacteria was recorded as the MIC.

Light and electron microscopy. Samples for light micrographs were stained with Victoria Blue $(1 \%, w / v)$ and fixed with an equal volume of $10 \%(\mathrm{v} / \mathrm{v})$ formaldehyde. Samples for electron microscopy were prepared and examined as described by Burdett \& Higgins (1978).

Enumeration and size distribution of bacteria. Organisms were grown in CYE medium which had been passed through a Millipore filter $(0.45 \mu \mathrm{m}, 4.5 \mathrm{~cm}$ diameter), fixed with an equal volume of filtered $10 \%(\mathrm{v} / \mathrm{v})$ formaldehyde, and suitably diluted in filtered $5 \%(\mathrm{w} / \mathrm{v})$ sodium chloride. The samples were counted using a Coulter counter, model FN, with a $0.30 \mu \mathrm{m}$ diameter orifice. The size distribution of bacteria within a sample was determined with a size distribution analyser, model P128, connected to the Coulter counter. Latex particles $(1 \cdot 15 \mu \mathrm{m}$ diameter $)$ were used for calibration.

Analysis of PBPs. Samples of membranes (approximately $100 \mu \mathrm{g}$ protein), prepared from C. perfringens 667 grown in the presence or absence of benzylpenicillin at $0.05 \mu \mathrm{g} \mathrm{ml}^{-1}$ for one generation, were incubated at $37^{\circ} \mathrm{C}$ for $10 \mathrm{~min}$ with increasing concentrations $(0.0045$ to $1.34 \mu \mathrm{g})$ of $\left[{ }^{3} \mathrm{H}\right]$ benzylpenicillin in a total volume of $50 \mu 1$ of $50 \mathrm{~mm}$-sodium phosphate buffer, $\mathrm{pH} 7 \cdot 0$. An excess of unlabelled benzylpenicillin $(600 \mu \mathrm{g})$ and $30 \mu \mathrm{l}$ of sample dilution buffer (Buchanan \& Strominger, 1976) were then added to each sample. Insoluble material was removed by centrifugation $\left(27000 \mathrm{~g}\right.$ for $15 \mathrm{~min}$ at $22^{\circ} \mathrm{C}$ ), and the samples analysed by slab polyacrylamide gel electrophoresis (Williamson et al., 1980).

The degree of saturation of individual PBPs in bacteria growing in the presence of varying concentrations of $\left[{ }^{3} \mathrm{H}\right]$ benzylpenicillin was determined as follows: samples $(1 \mathrm{ml})$ were taken at various times and mixed with $10 \mu \mathrm{l}$ of $10 \%(\mathrm{v} / \mathrm{v})$ Triton X-100 to stop further binding-protein synthesis. These were then treated in one of two ways. Either excess benzylpenicillin $(600 \mu \mathrm{g})$ was added and the organisms placed on ice, or further $\left[{ }^{3} \mathrm{H}\right]$ benzylpenicillin $(1 \mu \mathrm{g})$ was added and the organisms were incubated for $10 \mathrm{~min}$ at $37^{\circ} \mathrm{C}$ to fully saturate the PBPs; unlabelled benzylpenicillin $(600 \mu \mathrm{g})$ was then added. The bacteria were recovered from all samples by centrifuging $(4500 \mathrm{~g}$ for $10 \mathrm{~min}$ at $2{ }^{\circ} \mathrm{C}$ ) and resuspended in $50 \mu \mathrm{l}$ of $50 \mathrm{~mm}$-sodium phosphate buffer, $\mathrm{pH} 7 \cdot 0$, containing $0 \cdot 1 \%(\mathrm{v} / \mathrm{v})$ Triton $\mathrm{X}-100$ and $\mathrm{M} 1$-muramidase $(20 \mu \mathrm{g})$. After incubation at $37^{\circ} \mathrm{C}$ for $5 \mathrm{~min}$, lysis of the bacteria was complete. After addition of sample dilution buffer $(30 \mu \mathrm{l})$ the lysates were prepared for SDS-PAGE as described above.

Analytical methods. Hexosamines and amino acids were determined on a Beckman-Spinco amino acid analyser after hydrolysis of samples at $100^{\circ} \mathrm{C}$ in $4 \mathrm{M}-\mathrm{HCl}$ for $4 \mathrm{~h}$ and $6 \mathrm{M}-\mathrm{HCl}$ for $16 \mathrm{~h}$, respectively. Protein was determined by the Lowry method using bovine serum albumin as the standard. Walls of $C$. perfringens, isolated and purified as described previously (Williamson \& Ward, 1979) were treated with nitrous acid by the method of Fordham \& Gilvarg (1974), except that the final concentration of acetic acid was $0.85 \mathrm{M}$ and the lysozyme treatment was omitted. Walls were dinitrophenylated and hydrolysed as described by Forsberg \& Ward (1972). DNP-glycine was extracted from the hydrolysate into ether and purified by TLC on silica gel G60 (Camlab, Cambridge) in solvent A (chloroform/methanol/acetic acid: $95: 5: 1$, by vol.). DNP-hexosamines were extracted into butan-1-ol and separated by two dimensional chromatography as described by Araki et al. (1972). DNP-hexosamines were also subjected to electrophoresis on Whatman 3MM paper in buffer A (pyridine/acetic acid/water; $25: 1: 474$ by vol., $\mathrm{pH} \mathrm{6.5)}$ at $80 \mathrm{~V} \mathrm{~cm}^{-1}$ for $45 \mathrm{~min}$ and as their borate complexes in buffer $\mathrm{B}(0.06 \mathrm{M}$-sodium borate, $\mathrm{pH} 9.5)$ at $60 \mathrm{~V} \mathrm{~cm}^{-1}$ for $3 \mathrm{~h}$

Materials. Chemicals were of analytical grade where possible. Ampicillin and methicillin were supplied by Beecham Pharmaceuticals, Brentford, Middlesex, U.K., benzylpenicillin and cephaloridine by Glaxo, vancomycin by Eli Lilly, Basingstoke, Hants., U.K., and mecillinam by Leo Pharmaceuticals, Ballerup, Denmark. $p-\left[{ }^{3} \mathrm{H}\right]$ Benzylpenicillin, ethyl-piperidinium salt $\left(26 \mathrm{Ci} \mathrm{mmol}^{-1}\right)$ was obtained from E. O. Stapley, Merck, Sharp \& Dohme, Rahway, N.J., U.S.A. M1-muramidase was the generous gift of K. Yokogawa, Dainippon Pharmaceutical Co., Suita/Osaka, Japan, and was purified to homogeneity by the method of Siegel et al. (1981). Membranes were prepared from exponential phase organisms disrupted by passage through an Aminco French pressure cell (Williamson \& Ward, 1979), and suspended in $25 \mathrm{~mm}$-Tris/ $\mathrm{HCl}$ buffer, $\mathrm{pH} 7 \cdot 8$, containing 
$5 \mathrm{mM} \mathrm{MgCl}_{2}$, at about $3 \mathrm{mg}$ protein $\mathrm{ml}^{-1}$. Dinitrophenyl derivatives of galactosamine, glucosamine, mannosamine and muramic acid were prepared by the method of Araki et al. (1972). Penicillinase was obtained from Riker Labs, Loughborough, Leics., U.K.

\section{RESULTS}

Effect of benzylpenicillin on the growth and morphology of C. perfringens

Benzylpenicillin was added to $C$. perfringens strain 8237 in the exponential phase of growth to give concentrations of $0.03,0.06$ and $0.12 \mu \mathrm{g} \mathrm{ml}^{-1}$. The MIC of benzylpenicillin against $C$. perfringens 8237 is $0.3 \mu \mathrm{g} \mathrm{ml}^{-1}$. Samples were taken at intervals and the morphology of the bacteria examined by light and electron microscopy. The control organisms always grew as rods, but the antibiotic-treated clostridia were noticeably longer after two generations of growth and continued to grow apparently as filaments thereafter, since few septa were observed (Fig. 1). There appeared to be no difference in the effect of benzylpenicillin at the three concentrations tested. The electron micrographs of the untreated organisms showed them to be enclosed by a thick capsule. Cell division occurred by the ingrowth of a septum, followed by separation of the two bacilli starting at the periphery of the septum (Fig. $2 a, b$ ). After one generation of growth in the presence of benzylpenicillin, the developing septa appeared to be malformed and occasionally associated with membranous vesicles (Fig. $2 c, d$ ). With continued incubation of antibiotic-treated organisms, some of the regions where septa might have been expected to form showed indentations of the peripheral wall as though the structure of the walls were altered at these points. However, the indentations were not as marked as in those organisms examined after one generation of growth. Virtually all the clostridia incubated with benzylpenicillin for six generations grew as long filaments with no evidence of septa, although a few had slight indentations (Fig. 2e). The organisms continued to be bounded by the capsular material.

\section{Reversibility of filament formation}

Since benzylpenicillin rapidly inhibited septum formation and thus caused the organism to grow as filaments, penicillinase was added to antibiotic-treated $C$. perfringens NCTC 8237 to determine if filament formation was readily reversible. Benzylpenicillin $\left(0.03 \mu \mathrm{g} \mathrm{ml}^{-1}\right)$ was added to four of five exponential phase cultures, and penicillinase (40 units $\mathrm{ml}^{-1}$ ) was subsequently added at $30 \mathrm{~min}$ intervals to three of the antibiotic-treated cultures. Samples were taken at intervals for determination of the turbidity and enumeration of organisms (Fig. $3 a, b$ ). Although the turbidity increase of each culture was essentially the same for approximately five
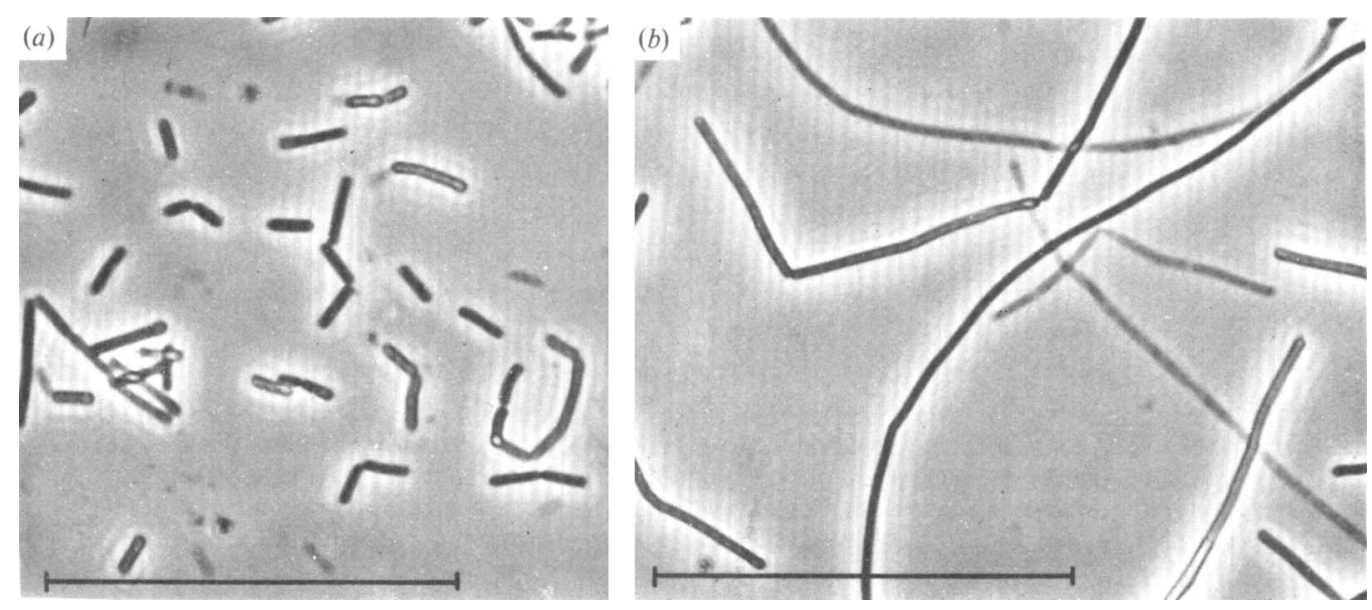

Fig. 1. Clostridium perfringens strain 8237 grown in $(a)$ the absence and $(b)$ the presence of benzylpenicillin $\left(0.05 \mu \mathrm{g} \mathrm{ml}^{-1}\right)$. The bar marker represents $5 \mu \mathrm{m}$. 

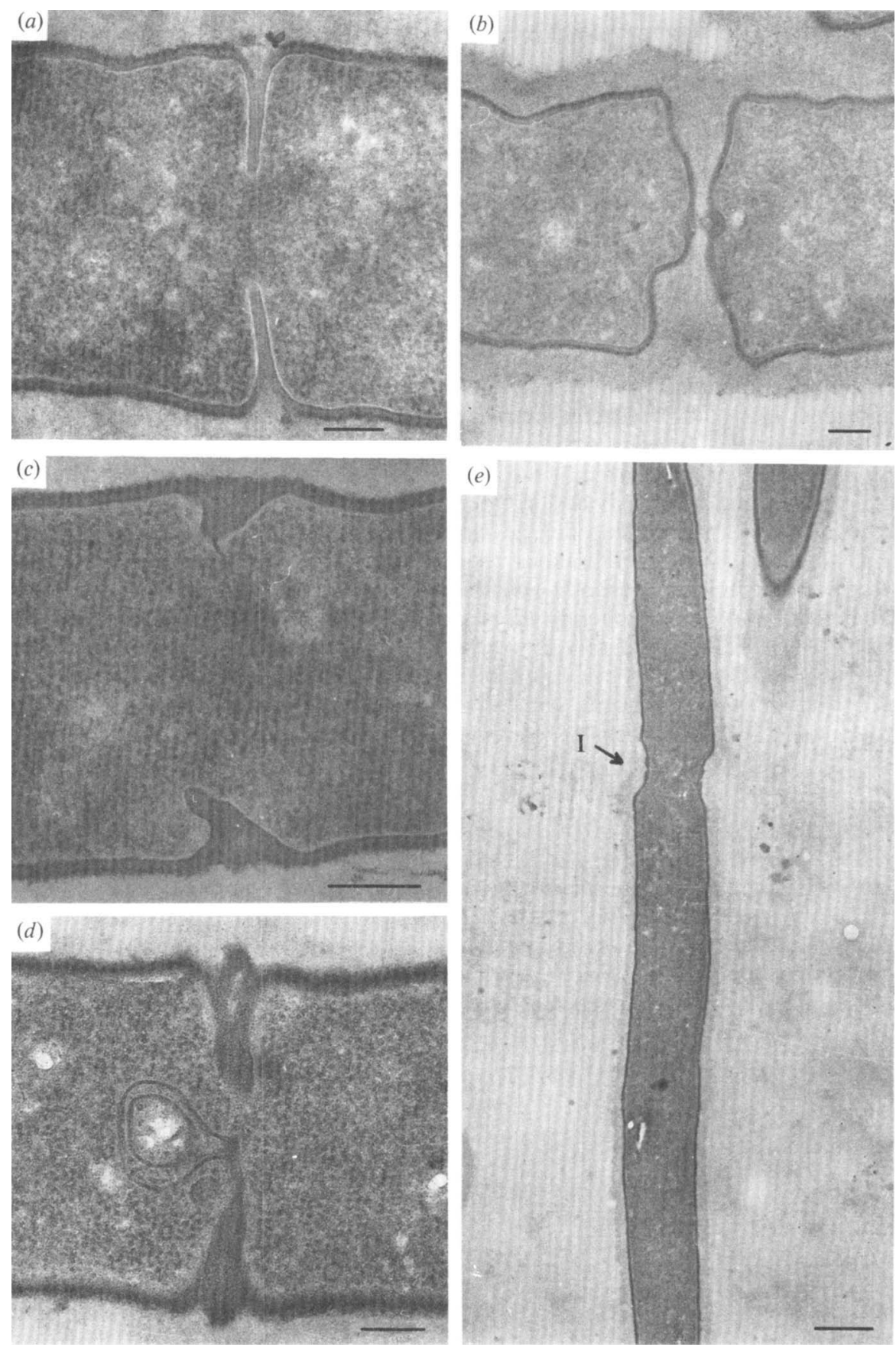

Fig. 2. Electron micrographs of $C$. perfringens strain 8237 showing $(a)$ ingrowth of the septum to separate two organisms $(b)$. The bacteria are enclosed by a thick capsule. After growth in the presence of benzylpenicillin for one generation the septa appear to be malformed $(c, d)$. After growth for six generations the organisms grew as long filaments with no evidence of septa (e) although indentations (I) in the wall were observed. In $a, b, c$ and $d$ the bar marker represents $0 \cdot 2 \mu \mathrm{m}$ and in $(e), 1 \cdot 0 \mu \mathrm{m}$.

generations, division virtually ceased about one generation after addition of the benzylpenicillin. Penicillinase clearly reversed the effect of the antibiotic some two generations after its addition. Some clumping of the filaments occurred in the cultures which were treated with 


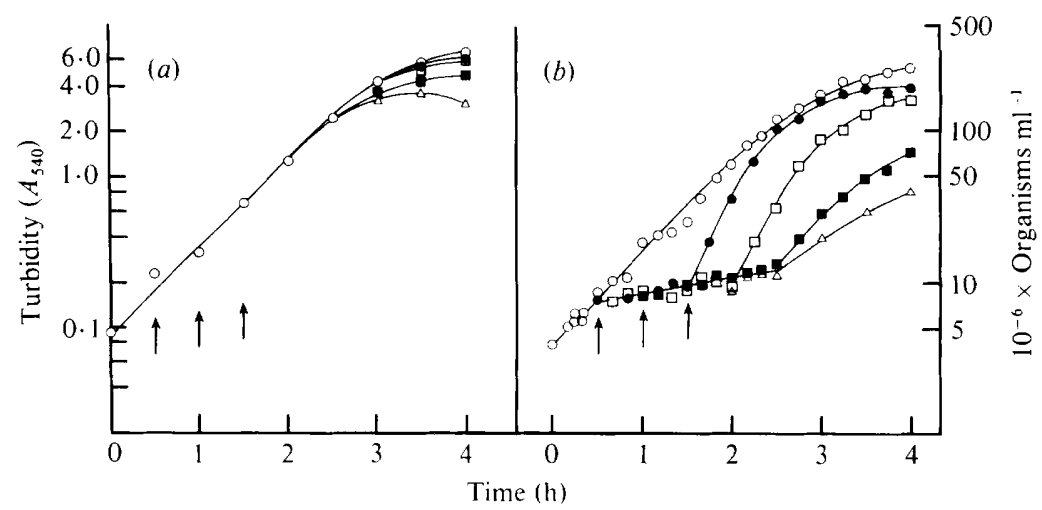

Fig. 3. Reversibility of inhibition of $C$. perfingens strain 8237 cell division by benzylpenicillin. Benzylpenicillin $\left(0.03 \mu \mathrm{g} \mathrm{ml}^{-1}\right)$ was added to organisms in the exponential phase of growth at time 0 and penicillinase (40 units $\mathrm{ml}^{-1}$ ) was added after $30(\bigcirc), 60(\bigcirc)$ and $90(\boldsymbol{0})$ min incubation (arrows). Control cultures received no additions $(O)$ and benzylpenicillin but no penicillinase $(\triangle)$. The figure shows $(a)$ the turbidity of the various cultures and $(b)$ the total number of organisms present.

benzylpenicillin for the longer times, and this would have given an underestimate of the actual number of organisms present. After $150 \mathrm{~min}$ incubation a small amount of lysis was observed in the culture containing benzylpenicillin but no penicillinase. This may have resulted in some breakage of the filaments present in this culture giving an apparent increase in the number of organisms present.

\section{Effect of other B-lactam antibiotics and vancomycin}

To determine whether the effect of benzylpenicillin was specific, cultures of $C$. perfringens NCTC 8237 in the exponential phase of growth were treated with other penicillins and cephalosporins and with vancomycin. After $3 \mathrm{~h}$ incubation the morphology of the organisms was examined by light microscopy. In addition to benzylpenicillin, ampicillin (MIC $0.3 \mu \mathrm{g} \mathrm{ml}^{-1}$ ), methicillin (MIC $1.0 \mu \mathrm{g} \mathrm{ml}^{-1}$ ) and cephaloridine (MIC $1.0 \mu \mathrm{g} \mathrm{ml}^{-1}$ ) caused filament formation at concentrations from 30 times less than the MIC up to the MIC for each antibiotic. On the other hand, mecillinam (MIC $200 \mu \mathrm{g} \mathrm{ml}^{-1}$ ) was less effective and in these cultures the majority of the clostridia grew as short filaments about four times the length of untreated organisms. Vancomycin (MIC $1 \cdot 0 \mu \mathrm{g} \mathrm{ml}^{-1}$ ) had no effect on division.

\section{Wall composition and peptide cross-linking of benzylpenicillin-treated organisms}

Since $\beta$-lactam antibiotics are known to inhibit transpeptidation and hence cross-linkage of peptidoglycan, the possibility that changes in the degree of cross-linkage were associated with filament formation in benzylpenicillin-treated clostridia was investigated. The walls of benzylpenicillin-treated and control organisms were hydrolysed and their content of amino acids and amino sugars determined. There were no significant differences between the two samples (Table 1). Attempts were made to determine the degree of cross-linking of the wall samples ( $5 \mathrm{mg}$ of each) by deamination with nitrous acid. In this way glycine residues not involved in cross-linkage (Leyh-Bouille et al., 1970) would be deaminated. Hence, the amount of glycine remaining in the wall would be a measure of cross-linkage of the peptidoglycan. However, both wall samples lost 80 to $90 \%$ of their initial turbidity during the treatment with nitrous acid. The remaining insoluble material was removed by centrifuging and the soluble fraction was desalted on columns of Sephadex G25. Analysis of the solubilized peptidoglycan from control walls showed that it contained glutamic acid, diaminopimelic acid, alanine and glycine in the molar proportions $1.00: 1 \cdot 01: 1.91: 0.74$. Thus $74 \%$ of the glycine residues in these walls appeared to be involved in cross-linkage. A value of $69 \%$ was obtained for walls from benzylpenicillin-treated clostridia. 
Table 1. Analysis of $C$. perfringens walls

Walls were prepared from organisms grown for six generations in the presence and absence of benzylpenicillin $\left(0.05 \mu \mathrm{g} \mathrm{ml}^{-1}\right)$.

\begin{tabular}{lcc}
\multicolumn{1}{c}{ Component } & $\begin{array}{c}\text { Composition } \\
{\left[\mu \mathrm{mol}(100 \mathrm{mg})^{-1}\right]}\end{array}$ \\
\cline { 2 - 3 } Muramic acid & $18 \cdot 1$ & $17 \cdot 6$ \\
Glucosamine & $17 \cdot 9$ & $18 \cdot 4$ \\
Galactosamine + mannosamine & $38 \cdot 2$ & $36 \cdot 4$ \\
Alanine & $54 \cdot 5$ & $58 \cdot 5$ \\
Glutamic acid & $31 \cdot 2$ & $30 \cdot 9$ \\
Diaminopimelic acid & $26 \cdot 1$ & 28.9 \\
Glycine & $29 \cdot 9$ & $27 \cdot 1$ \\
Phosphorus & $62 \cdot 5$ & $64 \cdot 2$
\end{tabular}

Nitrous acid degrades polymers containing hexosamines by deaminative depolymerization (Williams, 1975). It therefore seemed possible that the presence of hexosamines, rather than $\mathrm{N}$ acetylhexosamines, in the peptidoglycan of $C$. perfringens could have caused the solubilization of the walls by nitrous acid. SDS-walls $(2 \mathrm{mg})$ were dinitrophenylated, and the excess reagent and soluble material removed by repeated washing. The DNP-walls were then hydrolysed $(4 \mathrm{M}-\mathrm{HCl}$ for $4 \mathrm{~h}$ at $100^{\circ} \mathrm{C}$ ) and the DNP-amino acids and amino sugars extracted with diethyl ether and butan-1-ol. The ether extracts were chromatographed on silica gels in solvent A and the bands corresponding to DNP-glycine were scraped off and eluted. The amount of glycine recovered as the DNP-derivative was $21.6 \%$ and $22.8 \%$ of the total present in walls of control and benzylpenicillin-treated organisms, respectively. This measurement of the degree of crosslinkage was in good agreement with that obtained by acid deamination with nitrous acid.

The butan-1-ol extracts contained material corresponding to either DNP-glucosamine, DNPgalactosamine or DNP-mannosamine $\left(R_{\text {dinitrophenol }}=0.08\right)$ when chromatographed in solvent A. There were no spots corresponding to DNP-muramic acid and this was confirmed by electrophoresis of the DNP-hexosamines in buffer A at pH 6.5. The DNP-hexosamine isolated from clostridial walls chromatographed in a position identical with DNP-glucosamine in the two-dimensional system of Araki et al. (1972). The identity of the DNP-glucosamine was further confirmed by electrophoresis as the borate complex in buffer $\mathbf{B}$.

The walls of $C$. perfringens contained $10.8 \mu \mathrm{mol}$ glucosamine per $100 \mathrm{mg}$ dry wt. Hence approximately $40 \%$ of the glucosamine residues present were $N$-unsubstituted. Values of 26 to $100 \% \mathrm{~N}$-unsubstituted glucosamine were reported for walls of Bacillus cereus, B. megaterium and B. subtilis (Hayashi et al., 1973).

\section{PBPs of C. perfringens}

As described above, the inhibition by certain $\beta$-lactam antibiotics of PBP3 of $E$. coli has been correlated with filament formation (Spratt, 1975). To determined whether a similar situation exists in C. perfringens the interaction of benzylpenicillin with the PBPs of this organism was investigated. The phospholipase-deficient strain of $C$. perfringens (strain 667) was used for these studies since membranes were more readily obtained than from strain 8237 . However, both strains showed identical MICs of benzylpenicillin and identical PBPs on SDS-PAGE. Six PBPs were present in the membranes which showed an approximately 80 -fold difference in the amount of $\left[{ }^{3} \mathrm{H}\right]$ benzylpenicillin required to give $50 \%$ saturation of the individual PBPs (Table 2). When membranes were obtained from organisms grown with benzylpenicillin $\left(0.05 \mu \mathrm{g} \mathrm{ml}^{-1}\right)$, less radioactive antibiotic become bound to PBPs 3, 4, 5 and 6 .

The loss of $\left[{ }^{3} \mathrm{H}\right]$ benzylpenicillin from the complexes formed with the PBPs of $C$. perfringens was also examined and the half-lives of the complexes determined (Table 3). All complexes broke down, with a sixfold variation in rate; PBP1 lost radioactivity at the fastest rate, while PBP6 was the most stable. The addition of neutral hydroxylamine (as a nucleophilic donor) only 
Table 2. PBPs of C. perfringens

$\begin{array}{cccc}\text { PBP } & \begin{array}{c}\text { Apparent } \\ \text { mol. wt }\end{array} & \begin{array}{c}\text { Percentage } \\ \text { of total } \\ \text { binding }\end{array} & \begin{array}{c}\text { Concentration of } \\ {\left[{ }^{3} \mathrm{H}\right] \text { benzylpenicillin }} \\ \text { for } 50 \% \text { saturation } \\ \left(\mu \mathrm{g} \mathrm{ml}^{-1}\right)\end{array} \\ 1 & 125000 & 1 \cdot 7 & 1.85 \\ 2 & 103000 & 2 \cdot 8 & 2.90 \\ 3 & 90000 & 1.4 & 0.037 \\ 4 & 81000 & 9 \cdot 8 & 0.035 \\ 5 & 49000 & 23.4 & 0.065 \\ 6 & 45000 & 60.8 & 0.11\end{array}$

Table 3. Time required for release of $50 \%$ of the bound $\left[{ }^{3} \mathrm{H}\right]$ benzylpenicillin from the $P B P s$ of $C$. perfringens

\begin{tabular}{|c|c|c|c|c|c|}
\hline \multirow{3}{*}{$\begin{array}{c}\text { Addition ... } \\
\text { PBP }\end{array}$} & \multicolumn{5}{|c|}{ Time or stimulation factor } \\
\hline & \multirow{2}{*}{$\begin{array}{l}\text { None } \\
\text { Time } \\
(\min )\end{array}$} & \multicolumn{2}{|c|}{ Hydroxylamine } & \multicolumn{2}{|c|}{ 2-Mercaptoethanol } \\
\hline & & $\begin{array}{l}\text { Time } \\
(\min )\end{array}$ & $\begin{array}{l}\text { Stimulation } \\
\text { factor }\end{array}$ & $\begin{array}{l}\text { Time } \\
(\mathrm{min})\end{array}$ & $\begin{array}{l}\text { Stimulation } \\
\text { factor }\end{array}$ \\
\hline 1 & $17 \cdot 4$ & $4 \cdot 7$ & 3.7 & $11 \cdot 3$ & 1.5 \\
\hline 2 & $33 \cdot 5$ & 33.4 & $1 \cdot 0$ & $32 \cdot 1$ & $1 \cdot 0$ \\
\hline 3 & $52 \cdot 7$ & $13 \cdot 0$ & $4 \cdot 1$ & $32 \cdot 3$ & 1.6 \\
\hline 4 & $38 \cdot 9$ & $24 \cdot 1$ & $1 \cdot 6$ & $32 \cdot 6$ & $1 \cdot 2$ \\
\hline 5 & $57 \cdot 7$ & $53 \cdot 4$ & $1 \cdot 1$ & $55 \cdot 6$ & 1.0 \\
\hline 6 & $103 \cdot 5$ & $30 \cdot 3$ & 3.4 & $75 \cdot 6$ & $1 \cdot 4$ \\
\hline
\end{tabular}

appeared to stimulate the breakdown of complexes with PBPs 1, 3 and 6. Addition of 2mercaptoethanol had only a marginal effect.

\section{Correlation of the morphogenic effect of benzylpenicillin with the affinity of the} antibiotic for PBPS

Since the PBPs of membranes prepared from benzylpenicillin-treated organisms bound less of the $\left[{ }^{3} \mathrm{H}\right]$ benzylpenicillin than did those of normal bacteria, the binding of the radioactive antibiotic to the PBPs of organisms growing as filaments in the presence of the antibiotic was measured. Organisms (strain 667) were incubated with low concentrations of $\left[{ }^{3} \mathrm{H}\right]$ benzylpenicillin and samples removed to determine the effect on growth and the corresponding percentage saturation of the PBPs throughout the experiment. Growth, measured turbidimetrically, was not affected by any of the concentrations of antibiotic used until after $100 \mathrm{~min}$ of incubation. However, only the highest concentration of $\left[{ }^{3} \mathrm{H}\right]$ benzylpenicillin $\left(0.045 \mu \mathrm{g} \mathrm{ml}^{-1}\right)$ caused the virtual cessation of cell division (Fig. 4). Profiles of the size distribution of bacteria treated with antibiotic at $0.045 \mu \mathrm{g} \mathrm{ml}^{-1}$ were similar after either 1,2 or 3 generations of growth when compared with those of control organisms. This observation suggests that there was a uniform response of the population to the antibiotic. In contrast, the size distribution of bacteria in each sample treated with the lower concentrations of antibiotic were skewed towards those of untreated bacteria, indicating a non-homogeneous response of these populations. Calculation of the mean cell volumes (Fig. 5) showed that control organisms remained essentially the same size throughout exponential phase growth, whereas the bacteria treated with the highest concentration of $\left[{ }^{3} \mathrm{H}\right]$ benzylpenicillin approximately doubled in volume after the second and third generations. The bacteria incubated with the lower concentrations of the antibiotic also increased in volume, being least affected by the lowest concentration.

Throughout the experiment increasing amounts of $\left[{ }^{3} \mathrm{H}\right]$ benzylpenicillin became bound to the PBPs with the exception of PBPs 1 and 2. However, the total amount of PBPs determined by the addition of a saturating amount of radioactive antibiotic to each of the treated cultures at the 


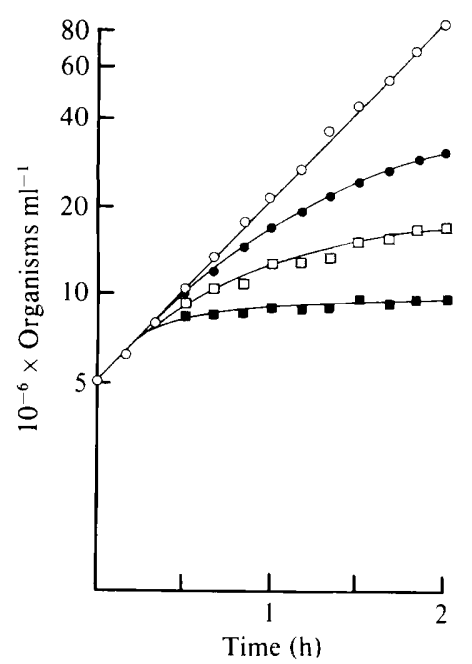

Fig. 4

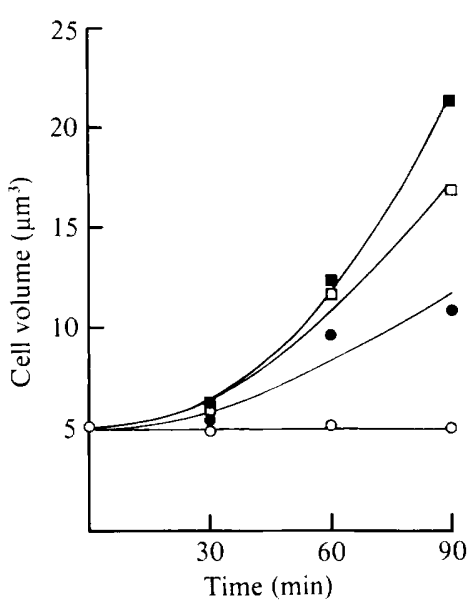

Fig. 5

Fig. 4. Inhibition of cell division of $C$. perfringens strain 8237 by benzylpenicillin. $\left[{ }^{3} \mathrm{H}\right]$ Benzylpenicillin at $0.0045(\bigcirc), 0.0143(\square)$ and $0.045(\square) \mu \mathrm{g} \mathrm{ml}^{-1}$ was added to organisms in the exponential phase of growth at $0 \mathrm{~min}$. Control organisms $(\mathrm{O})$ were grown in the absence of antibiotic.

Fig. 5. Mean cell volume of benzylpenicillin-treated organisms. The mean cell volumes were calculated from the size distributions of control organisms $(\mathrm{O})$ and bacteria growing in $\left[{ }^{3} \mathrm{H}\right]$ benzylpenicillin at $0.0045(\bigcirc), 0.0143(\square)$ and $0.045(\square) \mu \mathrm{g} \mathrm{ml}^{-1}$.

same time points was the same. Figure 6 shows the PBPs of $C$.perfringens grown in the presence of ${ }^{3} \mathrm{H}$ ]benzylpenicillin $\left(0.045 \mu \mathrm{g} \mathrm{ml}^{-1}\right)$ for $45 \mathrm{~min}$ and the total PBPs in a duplicate sample. The saturation of proteins of lower molecular weight ranged from $63.5 \%$ for PBP5 to $82.5 \%$ for PBP4. The percentage of saturation of PBPs 3 to 6 increased throughout the experiment, and the data for PBP6 are shown in Fig. 7. Similar profiles were obtained for the other PBPs. At the lower antibiotic concentrations the PBPs were significantly less saturated than those obtained from organisms treated with $0.045 \mu \mathrm{g} \mathrm{m}^{-1}$ of benzylpenicillin, the concentration which produced the homogeneous filamentation response of the population. Thus, at the lower antibiotic concentrations, the extents of saturation of the PBPs must have been below an average threshold value required to cause cessation of division.

\section{DISCUSSION}

The present studies have confirmed the early work of Gardner (1940) and Crofts \& Evans (1950) that suitable concentrations of benzylpenicillin, as well as some other $\beta$-lactam antibiotics, cause growth of $C$. perfringens as filaments. Thus the organism differs significantly in its response to this antibiotic when compared with other Gram-positive bacilli, such as Bacillus subtilis and B. licheniformis, which do not elongate under similar conditions (Highton \& Hobbs, 1971; Rogers, 1974).

The only other Gram-positive organism which has been reported to grow as filaments during treatment with a $\beta$-lactam antibiotic is Streptococcus bovis (Lorian \& Atkinson, 1976). Some parts of these filaments showed slight constrictions accompanied by a thickening of the wall. Similar constrictions were also found in the C. perfringens filaments, and they may be similar to the constrictive divisions of E. coli (Burdett \& Murray, 1974), which these authors suggested to be collapsed septa. Septa of $C$. perfringens which had been treated with benzylpenicillin for one or two generations were generally malformed. This condition may have resulted from the inhibition of further septal wall growth with some degradation of the pre-existing septum by the 
(a)

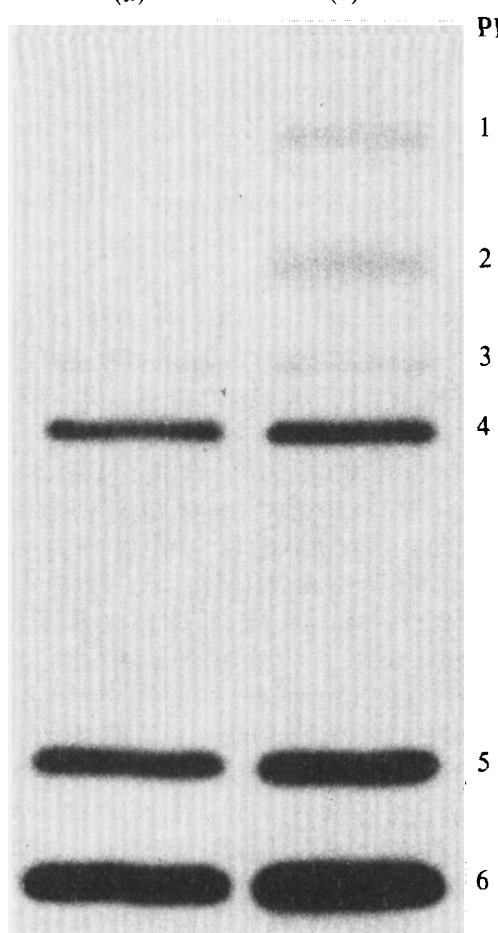

Fig. 6. PBPs of $C$. perfringens strain 667. The PBPs were labelled $(a)$ in organisms incubated with $\left[{ }^{3} \mathrm{H}\right]-$ benzylpenicillin $\left(0.045 \mu \mathrm{g} \mathrm{ml}^{-1}\right)$ for $45 \mathrm{~min}$, and $(b)$ after treatment of the membranes with an excess of $\left[{ }^{3} \mathrm{H}\right]$ benzylpenicillin.

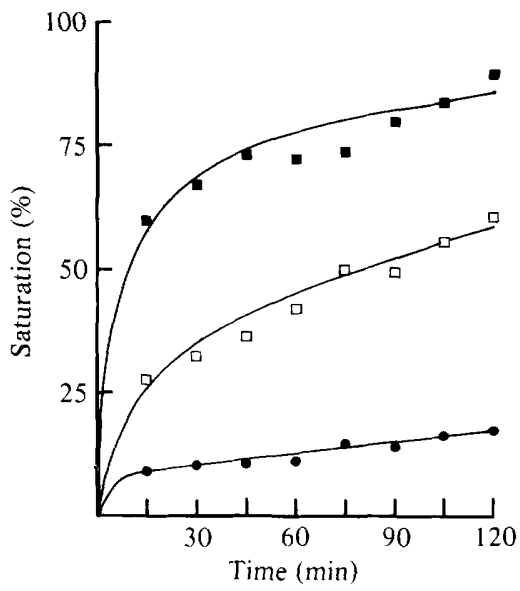

Fig. 7. Saturation kinetics of PBP6 in growing $C$. perfringens strain 667 . The percentage saturation values were calculated as described in the text using organisms growing in $\left[{ }^{3} \mathrm{H}\right]$ benzylpenicillin at $0.0045(\bigcirc), 0.0143(\square)$ and $0.045(\square) \mu \mathrm{g} \mathrm{m}^{-1}$.

autolytic enzymes. In this respect, autolysis of $C$. perfringens $\mathrm{S} 1114-3$ was reported to start by dissolution of one pole of the bacillus (Kawata \& Takumi, 1970).

Several authors (Hartmann et al., 1972; Lorian \& Atkinson, 1976; Zimmerman \& Stapley, 1976) have postulated that the growth of peripheral and septal walls are distinct processes. Thus the over-production of septa in some organisms such as Staphylococcus aureus (Lorian \& Atkinson, 1976; Tzagoloff \& Novick, 1977) or loss of septa would be due to differences in the 
relative sensitivities to inhibitors of the various components of the enzyme system controlling division compared with those involved in elongation. Thermosensitive, filament-forming mutants of Salmonella typhimurium (Ahmed \& Rowbury, 1971) and E. coli (Burdett \& Murray, 1974) were suggested to possess impaired autolytic activity during septation and division at the non-permissive temperature. However, the filaments induced by $\beta$-lactam treatment of $C$. perfringens were apparently not deficient in autolytic activity (R. Williamson \& J. B. Ward, unpublished observations). Thus the lack of cell division may result from inhibition of some synthetic activity rather than of a degradative process.

Fleck \& Mock (1972) compared the composition of walls from penicillin-induced filaments of Proteus vulgaris with walls from untreated organisms and concluded there were no biochemical differences. However, no estimation of the degree of cross-linking in the peptidoglycan was reported. In contrast, Mirelman et al. $(1976,1977)$ found that the peptidoglycan in filaments of $E$. coli was some $30 \%$ more cross-linked than that of normal rods. The authors suggested mechanisms whereby inhibition of DD-carboxypeptidase (or endopeptidase), whose activity was reduced in the filaments, would interfere with the ability to divide. Both these enzyme activities are penicillin-sensitive in E. coli (Bogdanovsky et al., 1969; Izaki et al., 1968). The analysis carried out in the present studies shows that the cross-linkage of the peptidoglycan of benzylpenicillin-induced filaments of $C$. perfringens is similar to that of organisms grown in the absence of the antibiotic. This may, however, reflect the relative resistance to inhibition by benzylpenicillin of the enzymes (transpeptidases) involved in the formation of the peripheral wall. Inhibition of septum formation could occur at the low penicillin concentrations used and any concomitant increase in the amount of non-cross-linked peptidoglycan might remain undetected in an analysis of the total wall. In B. subtilis, septa were calculated to represent approximately $15 \%$ of the total wall (Burdett, 1980).

As noted earlier, PBP3 appears either to control or to be directly involved in septum formation in E. coli. In contrast, no individual PBP of $C$. perfringens could be identified as a similar target for the morphogenic effect of benzylpenicillin. It is clear, however, that a concentration of $\left[{ }^{3} \mathrm{H}\right]-$ benzylpenicillin $\left(0.045 \mu \mathrm{g} \mathrm{ml}^{-1}\right)$ affects several PBPs and results in growth of virtually all the organisms as filaments after one generation. At this time PBPs 3, 4, $5 \& 6$ were all 65 to $70 \%$ saturated with antibiotic. Lower extents of saturation appeared to be insufficient to cause a uniform response. Even under conditions when these same PBPs were 90 to $100 \%$ saturated with $\left[{ }^{3} \mathrm{H}\right]$ benzylpenicillin there was no apparent interaction of the antibiotic with PBPs 1 and 2. These PBPs may have essential roles in growth of the peripheral wall and elongation of the organism. It is possible therefore that one or both of these proteins would have transpeptidase activity.

We thank Professors Howard J. Rogers and Alexander Tomasz, and Dr Ian Burdett, for many helpful discussions, and the latter also for the electron micrographs. We also thank Miss Sheila Lathwell for the amino acid analysis, and Mrs Carol Curtis, Dr Thomas Dougherty, and Dr Laurent Gutmann for assistance in some of the experiments. This work was initiated while one of us (R. W.) was in receipt of an MRC post-graduate studentship.

\section{REFERENCES}

Ahmed, N. \& Rowbury, R. J. (1971). Antibiotics and cell division in a filament-forming mutant of Salmonella typhimurium. Microbios 4, 181-191.

Araki, Y., NaKatani, T., Nakayama, K. \& Ito, E. (1972). Occurrence of $N$-nonsubstituted glucosamine residues in peptidoglycan of lysozyme-resistant cell walls from Bacillus cereus. Journal of Biological Chemistry 247, 6312-6322.

Bogdanovsky, D., Bricas, E. \& Dezelée, P. (1969). Identification of mucoendopeptidase and carboxypeptidase 1. Enzymes of Escherichia coli which hydrolyse bonds of $\mathrm{D}-\mathrm{D}$ configuration and are inhibited by penicillin. Comptes rendus hebdoma- daires des sèances de l'Academie des sciences 269, 309393.

Buchanan, C. E. \& Strominger, J. L. (1976). Altered penicillin-binding components in penicillin-resistant mutants of Bacillus subtilis. Proceedings of the National Academy of Science of the United States of America 73, 1818-1820.

BURDETT, I. D. J. (1980). Analysis of sites of autolysis in Bacillus subtilis by electron microscopy. Journal of General Microbiology 120, 35-49.

Burdett, I. D. J. \& Higgins, M. L. (1978). Study of pole assembly in Bacillus subtilis by computer reconstruction of septal growth zones seen in central, 
longitudinal thin sections of cells. Journal of Bacteriolog. 133, 959-971.

Burdett, I. D. J. \& Murray, R. G. E. (1974). Septum formation in Escherichia coli : characterisation of septal structure and the effects of antibiotics on cell division. Journal of Bacteriology 119, 303-324.

Crofts, J. E. \& Evans, D. G. (1950). The action of penicillin on Clostridium welchii type A. British Journal of Experimental Pathology 31, 550-561.

Curtis, N. A. C., Orr, D., Ross, G. W. \& Boulton, M. G. (1979). Competition of $\beta$-lactam antibiotics for the penicillin-binding proteins of Pseudomonas aeruginosa, Enterobacter cloacae, Klebsiella aerogenes, Proteus rettgeri and Escherichia coli: comparison with antibacterial activity and effects upon bacterial morphology. Antimicrobial Agents and Chemotherapy 16, 325-328.

Fleck, J. \& Mock, M. (1972). Etude de la forme filamenteuse de Proteus vulgaris P18 induite par la penicilline. Annales de l'Institut Pasteur 123, 319 332.

Fordham, W. D. \& Gilvarg, C. (1974). Kinetics of cross-linking of peptidoglycan in Bacillus megaterium. Journal of Biological Chemistry 249, 2478-2482.

ForsBerG, C. W. \& WARD, J. B. (1972). N-Acetylmuramyl-L-alanine amidase of Bacillus licheniformis and its L-form. Journal of Bacteriology 110, 878-888.

GARDNER, A. D. (1940). Morphological effects of penicillin on bacteria. Nature, London 146, 837-838.

Hartmann, R., Holtje, J.-V. \& Schwartz, U. (1972). Targets of penicillin action in Escherichia coli. Nature, London 235, 426-429.

Hayashi, H., ARaki, Y. \& Ito, E. (1973). Occurrence of glucosamine residues with free amino groups in cell wall peptidoglycan from bacilli as a factor responsible for resistance to lysosyme. Journal of Bacteriology 113, 592-598.

Highton, P. J. \& HobBs, D. G. (1971). Penicillin and cell wall synthesis: a study of Bacillus licheniformis by electron microscopy. Journal of Bacteriology 106, 646-658.

Iida, K., Hirata, S., Nakamuta, S. \& Koike, M. (1978). Inhibition of cell division of Escherichia coli by a new synthetic penicillin, piperacillin. Antimicrobial Agents and Chemotherapy 14, 257-266.

IZaki, K., Matsuhashi, M. \& Strominger, J. L. (1968). Biosynthesis of the peptidoglycan of bacterial cell walls. XIII. Peptidoglycan transpeptidase and Dalanine carboxypeptidase; penicillin-sensitive enzymatic reactions. Journal of Biological Chemistry 243, 3180-3192.

KaWATA, T. \& TaKumi, K. (1970). Initiation sites of autolysis in Clostridium perfringens type $\mathrm{A}$ as revealed by electron microscopy. Journal of General and Applied Microbiology 16, 341-345.

Leyh-Bouille, M., Bonaly, R., Ghuysen, J.-M., Tinelli, R. \& TiPPER, D. J. (1970). L,L-Diaminopimelic acid-containing peptidoglycans in walls of Streptomyces sp. and of Closteridium perfringens (type A). Biochemistry 9, 2944-2952.
LORIAN, V. \& AtKinson, B. (1976). Effects of subinhibitory concentrations of antibiotics on crosswalls of cocci. Antimicrobial Agents and Chemotherapy 9, 1043-1055.

Mirelman, D., Yashouv-Gan, Y. \& Schwarz, U. (1976). Growth pattern of peptidoglycan: biosynthesis in a thermosensitive division mutant of Escherichia coli. Biochemistry 15, 1781-1790.

Mirelman, D., Yashouv-Gan, Y. \& Schwarz, U. (1977). Regulation of murein biosynthesis and septum formation in filamentous cells of Escherichia coli PAT 84. Journal of Bacteriology' 129, 1539-1600.

Noguchi, H., Matsuhashi, M. \& Mitsuhashi, S. (1979). Comparative studies of penicillin-binding proteins in Pseudomonas aeruginosa and Escherichia coli. European Journal of Biochemistry 100, 41-49.

Pollock, M. R. (1965). Purification and properties of penicillinases from two strains of Bacillus licheniformis: a chemical, physicochemical and physiological comparison. Biochemical Journal 92, 666-675.

Rogers, H. J. (1974). Peptidoglycans (mucopeptides): structure, function, and variations. Annals of the New York Academy of Science 235, 29-51.

Siegel, J. L., Hurst, S. F., Liberman, E. S., Coleman, S. E. \& Bleiweis, A. S. (1981). Mutanolysin-induced spheroplasts of Streptococcus mutants are true protoplasts. Infection and Immunity 31, 808-815.

SpRatT, B. G. (1975). Distinct penicillin-binding proteins involved in the division, elongation and cell shape of Escherichia coli. Proceedings of the National Academy of Science of the United States of America $\mathbf{7 2}$, 2999-3003.

SpratT, B. G. (1977). Temperature-sensitive cell division mutants of Escherichia coli with thermolabile penicillin-binding proteins. Journal of Bacteriology 131, 293-305.

SPRATT, B. G. (1978). Escherichia coli resistance to $\beta$ lactam antibiotics through a decrease in the affinity of a target for lethality. Nature, London 274, 713-715.

Spratt, B. G. \& PardeE, A. (1975). Penicillin-binding proteins and cell shape in Escherichia coli. Nature, London 254, 516-517.

TZAGolofF, H. \& Novick, R. (1977). Geometry of cell division in Staphylococcus aureus. Journal of Bacteriology 129, 343-350.

Williams, J. M. (1975). Deamination of carbohydrate amines and related compounds. Advances in Carbohydrate Chemistry and Biochemistry 31, 9-79.

WILlIAMSON, R. \& WARD, J. B. (1979). Characterization of the autolytic enzymes of Clostridium perfringens. Journal of General Microbiology 114, 349-354.

Williamson, R., HaKenbeck, R. \& Tomasz, A. (1980). The penicillin-binding proteins of Streptococcus pneumoniae grown under lysis-permissive and lysisprotective (tolerant) conditions. FEMS Microbiology Letters 7, 127-131.

Zimmerman, S. B. \& Stapley, E. O. (1976). Relative morphological effects induced by cefoxitin and other $\beta$-lactam antibiotics in vitro. Antimicrobial Agents and Chemotherapy 9, 318-326. 